\title{
EDUCATION IN ENGINEERING - CHALLENGES AND CONTRIBUTIONS
}

\author{
Vyarka Ronkova \& Yuliyan Dimitrov
}
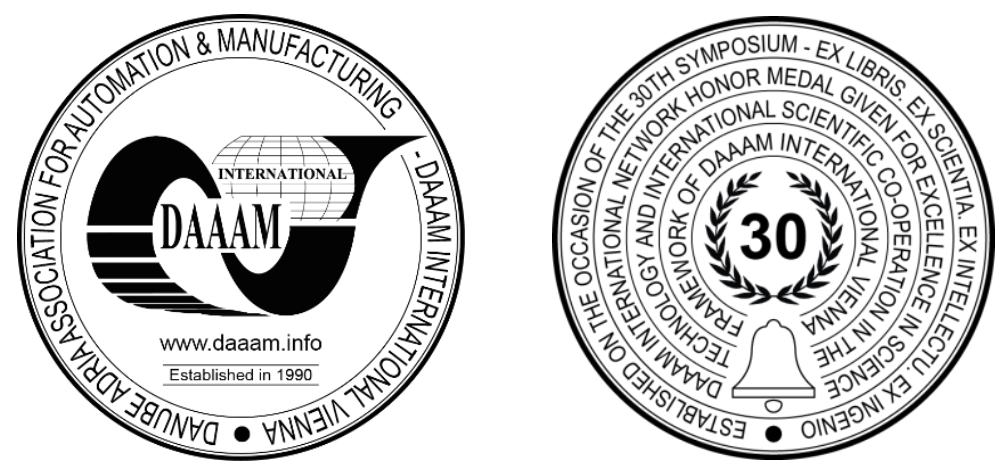

This Publication has to be referred as: Ronkova, V[yarka] \& Dimitrov, Y[uliyan] (2019). Education in Engineering Challenges and Contributions, Proceedings of the 30th DAAAM International Symposium, pp.0717-0723, B. Katalinic (Ed.), Published by DAAAM International, ISBN 978-3-902734-22-8, ISSN 1726-9679, Vienna, Austria DOI: $10.2507 / 30$ th.daaam.proceedings.098

\begin{abstract}
The paper presents a survey of possible solutions concerning the problems and challenges occurring nowadays in European higher engineering education. The objective of the investigation presented are the opportunities of developing in engineering students such extremely important competences as: creative abilities and skills for decision making through improving the quality of the study process. The main methods to achieve this goal are questionnaire survey conducted in various engineering Bachelor degree courses and tools for improving the communication between university management, faculty and students. The feedback received in this study is especially valuable concerning the students' opinion on the accessibility of the study material provided, the logical consistency between the topics, and the visual presentation of the knowledge. The authors have created a questionnaire based upon the experience from different European universities including University of Ruse, Bulgaria. The results obtained from this survey are compared and summarized. Conclusions have been made about the importance of students' evaluation of the lectures, tutorials, exercises and academic staff presentations and the role of this evaluation process for the improvement of the quality of education.
\end{abstract}

Keywords: Education in Engineering; Creative abilities; Decision making skills; Questionnaire survey; Quality of Higher education.

\section{Introduction}

Since 2007, there has been a constant shortage of qualified engineers in Bulgaria and in other eastern European countries. Therefore, the higher education in engineering faces serious problems and challenges, [1]. On the one hand, there is a need to train a large number of students in important engineering degree programs, and on the other hand, there is a steady tendency for lack of willingness on behalf of young people wishing to study mechanical and general engineering, [2].

The group of fundamental subjects in the field of engineering graphics, machine science and design are studied in the first years of the bachelor degree. Therefore, it is especially important that they cause interest in young people and the students and future students will not be afraid and unwilling to study and learn them, [3].

The academic staff teaching „Design" subjects has to present drawings, schemes, algorithms and diagrams. Usually, the lecturers apply CAD and CAM products at every stage of the teaching and learning process, [4]. In addition to calculations, "Design" stage can also include experimental part supported by simulations, [5] and [6]. 
To simplify the understanding of Design issues for particular domain it is also possible to create the virtual 3D rooms for professional activities as described in [7].

As a consequence of the above mentioned challenges for the academic staff working in the field of higher engineering education, the author's team set an objective to investigate the possibilities of developing better creative abilities and skills for decision making in engineering students by improving the quality of the study process. The author' team considers that the main methods to achieve this goal have to be a questionnaire survey conducted in various engineering Bachelor degree courses and tools for improving the communication between university management, faculty and students.

There is a traditional tendency at the University of Ruse to look for a feedback from students by studying their opinions through questionnaires. This approach is an effective tool for correcting the management of the study process and to raise the quality of education. The feedback received from the students consists of applying different strategies and methods for constant and systematic research of their opinions about the training obtained. The objective of the questionnaire survey is to cause a discussions between the university management, academic staff and students, which would contribute to increasing the quality of teaching, study process and learning environment [8], [9].

The objective of the questionnaire survey presented in this paper leads to defining the following investigation tasks: to evaluate the study process concerning the subjects delivered at the Department of Machine Science, Machine Elements, Engineering Graphics and Physics (MMEEG \& Physics) at the University of Ruse based upon the information gathered through the questionnaire survey; to evaluate the quality of syllabi developed; to assess the teaching skills of the academic staff and the quality of the study material delivered.

The questionnaires presented are aiming at obtaining information about the quality of academic subjects, concerning the contents of the lecture course, the practical and laboratory tutorials, the quality of the lecturing and presenting of the learning materials. The most important objective of the questionnaires created is the obtaining of topical and maximum credible information from students' point of view concerning the learning material of subjects belonging to the Department of MMEEG \& Physics.

The target groups of the research are students from the professional areas of Mechanical Engineering and General Engineering, who are having their first, second or third year of study within the relevant Bachelor degree program. Due to the large number of students, the questionnaire investigation has been conducted stochastic - representative (partially): with selected groups of different years of study and of various Bachelor degree programs attending different lecture courses. The questionnaires have been implemented entirely anonymously due to the following reason: previous investigations from past years concluded that the open character of the questionnaire survey did not affect the way of response distribution [8], [9], [10].

\section{Questionnaire structure}

For about 9 academic years (since 2011), the authors' team has been conducting such kind of research. The results included in this paper are based on a questionnaire survey implemented during the academic 2018/2019 year. The questionnaire contents have been elaborated based upon the existing experience at the University of Ruse and upon the practice of other European universities, [11], [12] and [13].

The questionnaires consist of three parts: 1) Preparatory data unit; 2) List of questions; 3) Remark and comment. The preparatory data unit gives information about the time and place of questionnaire implementation, the name of the lecturer and the subject for which the students give their opinions. Explanations are provided concerning: who is carrying out the questionnaire survey and why. Necessary comments and instructions are given additionally in case the students need more information (Table 1).

\begin{tabular}{|l|l|}
\hline Date & University \\
\hline Lecturer's Name & \\
\cline { 1 - 1 } Subject & \\
\hline
\end{tabular}

Table 1. Preparatory data unit

The questionnaires consist of 13 statements (Q1-Q13), (Table 2). These assertions are the main part of the questionnaire survey. The authors have made great efforts to create unambiguous, logical and systematic contents. The questions are implicit, by means of which the students are given the opportunity to express their agreement or disagreement with the statement. In case the students do not have an opinion: it can also be reflected.

Three levels of the acceptance of the statements made are envisaged (Table 3 ).

The questions are focused mainly on the contents of the study material delivered. The following issues are especially important: Is there an understandable structure and logical sequence of the study material?; Does the theory have clear references to practice?; Is the time dedicated to lectures used in a rational way?

The questions concerning the sufficiency of the lecture hours provided are of particular interest for the appropriate preparation process of new syllabi. The quantity of lecture hours and opportunity for providing all the knowledge for the successful implementation of practical and laboratory exercises and tutorials within the subject investigated are of great importance. 


\begin{tabular}{|c|l|}
\hline Q1. & The lecture material delivered is structured in a comprehensible and logical way. \\
\hline Q2. & The lectures' content of the subject is current and topical. \\
\hline Q3. & $\begin{array}{l}\text { The exercises and tutorials within the subject are in logical connection with the lectures } \\
\text { delivered, they are complementing and clarifying them. }\end{array}$ \\
\hline Q4. & $\begin{array}{l}\text { Appropriate practical examples illustrate the subject theory, they are given as tasks in practical } \\
\text { and laboratory tutorials and exercises. }\end{array}$ \\
\hline Q5. & Academic time (lectures, tutorials, etc.) is used reasonably. \\
\hline Q6. & $\begin{array}{l}\text { More academic time is required for perception, assimilation and learning of the subject } \\
\text { material. }\end{array}$ \\
\hline Q7. & $\begin{array}{l}\text { Modern tools were used to present lectures (with graphic represenations, figures, tables), the } \\
\text { exercises and tutorials were provided with good and upgrated equipment and facilities } \\
\text { (visualization materials, experimental test machines). }\end{array}$ \\
\hline Q8. & $\begin{array}{l}\text { The lecturer speaks clearly, understandably, in a correct academic language, he/she organizes } \\
\text { the exercises methodically and systematically and he/she answers students' questions in a } \\
\text { professional way, adhering to the academic ethics. }\end{array}$ \\
\hline Q9. & The study material delivered and its presentations create motivation and interest in subject. \\
\hline Q10. & $\begin{array}{l}\text { The lecture material is a necessary and sufficient basis for the practical and laboratory } \\
\text { exercises and tutorials within the relevant subject. }\end{array}$ \\
\hline Q11. & $\begin{array}{l}\text { Practical exercises and laboratory tutorials are prerequisites for the successful fulfillment of } \\
\text { independent extracurricular work. }\end{array}$ \\
\hline Q12. & $\begin{array}{l}\text { The lectures have essential importance for the good students' performance during the subject's } \\
\text { exam. }\end{array}$ \\
\hline Q13. & $\begin{array}{l}\text { The tasks solved during the exercises and the independent extracurricular work prepare the } \\
\text { students for their successful performance in control tests and examinations. }\end{array}$ \\
\hline
\end{tabular}

Table 2. List of questions

\begin{tabular}{|l|l|}
\hline \multicolumn{2}{|c|}{ Please, check $(v, x)$ in the box consistent with your opinion } \\
about the corresponding statement.
\end{tabular}

Table 3. Scale for accepting the questionnaire statements

An opportunity is given to the students to comment and make general remarks concerning the subject already finished in the last part of the questionnaires: Remark and comment. In this part, the students can express their opinions about the lecturer in terms of his/her preparation of teaching presentations, model of behaviour and visualization tools applied.

\section{Results and Discussions}

The results of the survey investigation depend on the type of questions included in the questionnaire. This type of questionnaires strives to cover all aspects of education process: competences and pedagogical skills of lecturers, contents of the study material, type of tests and examinations, requirements for successful completion of subject course, communications between lecturers and students, learning environment.

1. Concerning the first question: A significant part (95.12\%) of the students believe that the lecture material delivered is presented in an understandable, comprehensible and logically related way; $2.44 \%$ of the students have no opinion on the matter and $2.44 \%$ of the students disagree with this statement. It can be concluded that the majority of students understand the lecture material provided. These results show as well a tendency for increasing the number of students who give a positive assessment on this issue compared to previous years' research. 


\begin{tabular}{|c|c|c|c|}
\hline & $\mathrm{A} 1$ & $\mathrm{~A} 2$ & $\mathrm{~A} 3$ \\
\hline $\mathrm{Q} 1$ & $95.12 \%$ & $2.44 \%$ & $2.44 \%$ \\
\hline $\mathrm{Q} 2$ & $97.56 \%$ & $0.00 \%$ & $2.44 \%$ \\
\hline $\mathrm{Q} 3$ & $93.90 \%$ & $4.88 \%$ & $1.22 \%$ \\
\hline $\mathrm{Q} 4$ & $93.90 \%$ & $6.10 \%$ & $0.00 \%$ \\
\hline Q5 & $92.68 \%$ & $6.10 \%$ & $1.22 \%$ \\
\hline Q6 & $51.22 \%$ & $34.15 \%$ & $14.63 \%$ \\
\hline Q7 & $95.12 \%$ & $2.44 \%$ & $2.44 \%$ \\
\hline Q8 & $98.78 \%$ & $1.22 \%$ & $0.00 \%$ \\
\hline Q9 & $79.27 \%$ & $4.88 \%$ & $15.85 \%$ \\
\hline Q10 & $82.93 \%$ & $7.32 \%$ & $9.76 \%$ \\
\hline Q11 & $93.90 \%$ & $2.44 \%$ & $3.66 \%$ \\
\hline Q12 & $93.90 \%$ & $4.88 \%$ & $1.22 \%$ \\
\hline Q13 & $90.24 \%$ & $4.88 \%$ & $0.48 \%$ \\
\hline
\end{tabular}

Table 4. Results shown in \%

2. Considering the question dealing with the topicality of the lectures contents and the reflection of the current topics' state: A great part (97.56\% of the students responded positively and $2.44 \%$ of the students did not have an opinion on this issue. Therefore, the results obtained give a positive assessment of these lectures, which are periodically updated and renewed.

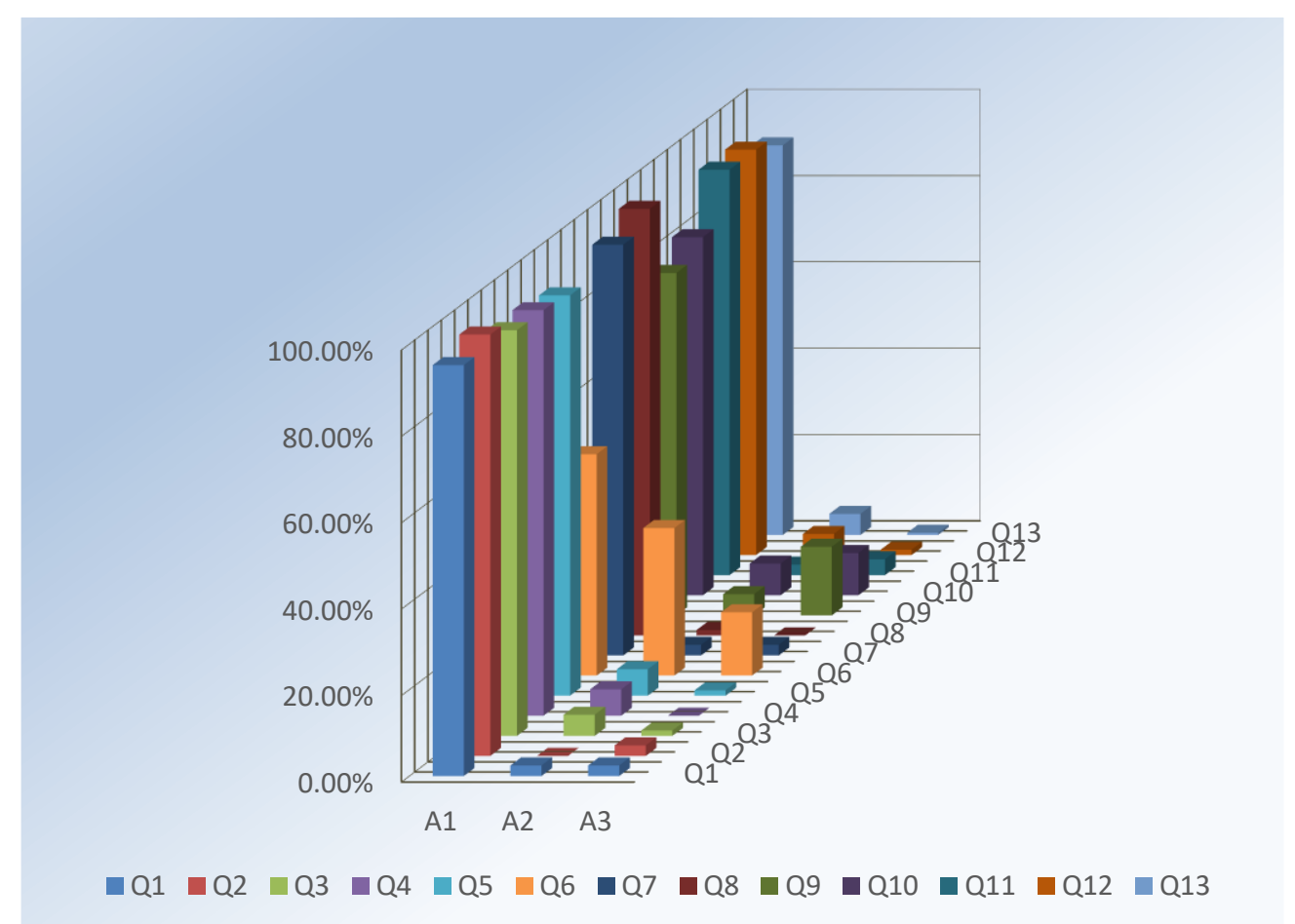

Fig. 1. Results from questionnaire investigation 
3. Concerning the logical relation between tutorials and lecture material, $93.9 \%$ of the students respond positively, $4.88 \%$ - with NO and $1.22 \%$ of the students have no opinion. That is why the conclusion is: the majority of students perceives and connects the theoretical part of the material delivered with the practical experience.

4. The question about the practical illustration of the study material involved in the exercises also received an affirmative answer from about $93.9 \%$ of respondents. The negative answers are $6.1 \%$.

5. The rational usage of time is an indicator which evaluates students' concentration of attention to lecturers and how the students' themselves organize their time for learning on their own. Concerning question Q5: about 92.68\% of the students gave a positive assessment, $1.22 \%$ of the students did not have an opinion on that matter and $6.1 \%$ of the students wrote that the study process time was incorrectly used.

6. An important question for assessing the sufficiency of the lectures envisaged (for the corresponding subject) is Q6. This is a indicator for the appropriate subject syllabi development. Nearly 52\% of the students believe that it is necessary to increase the quantity of lectures in order to improve the perception and assimilation options of the learning material. About $34 \%$ of the students are satisfied with the amount of lectures and exercises delivered. About $14.6 \%$ of the students do not give an opinion on this question.

7. Concerning the quality of lectures and better visualization of the learning material presented, it is particularly important to use modern means of presentation as well as to provide a good and modern facilities and equipment in order to improve the visualization of the exercises and tutorials. The descriptive schemes, examples, diagrams, figures and tables contribute significantly to the perception of the theory. About $95 \%$ of the students appreciate to a high extend the quality of the presentation during lectures, $2.44 \%$ of the students consider that the presentations can be improved and $2.44 \%$ of the students have no opinion on the question.

8. The personal evaluation of the verbal and communication skills of the lecturer/assistant professor can be seen in Q8 answers. Nearly $98.78 \%$ of the students give a high assessment of the academic staff. Only $1.22 \%$ of the students give a negative rating. There is a ssustainable share of high scores over the years, which is a good attestation for the academic staff at the University of Ruse.

9. It is especially valuable to meet the students' expectations and to ensure their interest in the subjects they are attending. When answering question nine, about $79.27 .4 \%$ of the students find it motivating to visit and listen to the subject taught. $15.85 \%$ of the students have no opinion on their interest in the subject and $4.88 \%$ of them are not interested at all.

10. How much lectures are needed and a sufficient basis for further practical and laboratory exercises and tutorials: Almost $82.93 \%$ of the students surveyed are satisfied with the knowledge acquired during lectures; they apply afterwards this knowledge during exercises and tutorials; $9.76 \%$ of the students have no opinion on this question and $7.32 \%$ of the students did not find any link between lectures and exercises.

11. This question relates to the sufficiency of the syllabi exercises and consultations needed as fundamentals for developing the graphical part of the assignment and project work in the corresponding subject. A significant proportion of students (93.9\%) give a positive answer, while those who consider the time to be insufficient are $2.44 \%, 3.66 \%$ of respondents on this issue have no opinion.

12. The lectures make a significant contribution to the successful completion of a particular subject and to the good results of final exams and tests. Almost $93.9 \%$ of the student agree with this statement, $1.22 \%$ have not determined their position on this matter and only $4.88 \%$ do not believe that the lectures have prepared them enough for a good final subject's performance.

13. The extent to which the exercises and consultations played a positive role for good performance in the subject investigated is assessed by Q13. A satisfaction is expressed by $90.24 \%$ of the students. This is a mark that the quality of training in a certain subject largely depends upon the student's work during lectures and tutorials. The negative response rate is $4.88 \%$. It is noted that the assessment of the respondents is practically the same for the role of lectures and exercises.

In the last part of the questionnaires "Remark and comment", the students have further indicated the need for more academic hours for presenting more subject's topics. They expressed their interest for more extensive (in details) presentations of the subject study material.

Some students described the advantage of linking the content of engineering subjects with the scientific contributions of European researchers. This circumstance intensifies the students' interest in the relevant subject [14], [15] and [16].

Another significant group of students is particularly pleased with the opportunities to attend extracurricular training, such as the "SMART in CAD" club meetings [17] and [18].

These two characteristics of the study process at the Department of "MMEEG and Physics" significantly contribute to the development of students' creative thinking and design skills. Almost all students elaborate their assignments and projects on time, they accumulate new knowledge and skills in creating design products and increase their sense of satisfaction with the results obtained.

The decision-making process for the inclusion of these two additional academic teaching activities was initiated based upon previous research investigations of the authors' team and the diagnosis of the study process in fundamental engineering subjects at the University of Ruse, [2] and [8]. 


\section{Conclusions and recommendations}

The information obtained from the students' feedback was essential for the evaluation of the academic staff and the quality of the study material delivered. Such surveys at the end of each training course are of particular importance to all academic lecturers in order to be aware to what extent he/she meets students' expectations and requirements. In case of mismatches of views, it is possible to correct the imperfections on time. The students' opinion is particularly important about: the time usage during academic study process; the necessity for corrections or the introduction of additional topics; the logical links between practical exercises and lectures delivered.

This feedback enables students to participate in the organization of the study process directly, through expressing their opinions. Thus, they take part in the management of the quality of the academic study and learning process.

The authors recognize that study syllabi and curricula always need improvements and changes in order to be meet the necessary new requirements for future engineers. And the next step to be done in this area will be a review of the contents of study syllabi and curricula. When updating these academic documents, attention will be paid to encourage the development of students' creative abilities: to become more innovative, more independent and to help them develop skills for decision-making.

Besides acquiring new knowledge and skills, the students should be also given the opportunities to apply their competences in practical work through their participation in various events, conferences, and professional clubs, in scientific and international activities. The students' participation in scientific and international activities will expand their knowledge in their future professional field and they will become more familiar with the business environment and the opportunities for realization after completing their education, which is a difficult process nowadays.

By assisting students concerning their realization on the labor market, this in turn will increase the positive attitude towards the engineering profession. Namely, this positive attitude will drive students to promote engineering education and will lead to increasing the number of future applicants willing to study Engineering. An important contribution in this area will be the students' participation in the Innovative Youth EXPO Forum at the University of Ruse, in which students present their work and some new products to the public community and to new applicants for engineering education.

The authors' future research plans are to extend the investigation presented through creating new questionnaires related to the evaluation of the training and education quality in the area of students' practical assignments, project work and development of new design products. The objective of this future research will be to measure the efficiency of students' activities in the professional club "SMART in CAD", in scientific conferences and in other university events.

The authors' team considers that this practical approach for implementing questionnaire survey should be carried out at every possible level of the university structure: university management, faculties and departments in order real and beneficial results to be achieved.

\section{Acknowledgments}

The research implemented is supported by the contract of University of Ruse, № BG05M2OP001-2.009-0011-C01, "Support for the development of human resources for research and innovation at the University of Ruse "Angel Kanchev". The project is funded by the Operational Program "Science and Education for Smart Growth 2014 - 2020 ", financed by the European Social Fund of the European Union.

\section{References}

[1] Shevtshenko, E.; Karaulova, T.; Igavens, M.; Strods, G.; Tandzegolskiene, I.; Tutlys, V.; Tavahodi, S. \& Kuts, V. (2017). Dissemination of Engineering Education at Schools and its Adjustment to Needs of Enterprises, Proceedings of the 28th DAAAM International Symposium, pp. 0044-0053, B. Katalinic (Ed.), Published by DAAAM International, ISBN 978-3-902734-11-2, ISSN 1726-9679, Vienna, Austria, DOI: $10.2507 / 28$ th.daaam.proceedings.006

[2] Kamenov, K.; Dobreva, A. \& Ronkova, V. (2017). Advanced Engineering Methods in Design and Education, Material Science and Engineering, IOP Publishing, No 252, pp. 012033 - 37, ISSN 1757 - 8981.

[3] Dobreva, A.; Angelova E.; Ronkova, V.; Haralanova, V. \& Dimitrov, Y. (2012). Students' Participation in the Management of the Quality of Education Process, Management \& Sustainable Development, Vol 14, No 1, pp. 2226, ISSN 1311-4506

[4] Dimitrov, Y. (2018). System for Automatic Distribution and Working with Technical Documentation in Small and Micro-Sized Industrial Enterprises, Proceedings of the 29th DAAAM International Symposium, pp.0976-0982, B. Katalinic (Ed.), Published by DAAAM International, ISBN 978-3-902734- 20-4, ISSN 1726-9679, Vienna, Austria, DOI: $10.2507 / 29$ th.daaam.proceedings. 140

[5] Stoyanov, S.; Dobrev, V. \& Dobreva, A. (2017). Finite Element Contact Modelling of Planetary Gear Trains, Material Science and Engineering, IOP Publishing, No 252, pp. 012034 - 38, ISSN 1757 - 8981.

[6] Dobreva, A. (2013). Theoretical Investigation of the Energy Efficiency of Planetary Gear Trains., Mechanisms and Machine Science, No 13, pp. 289-298, ISSN 978-94-007-6558-0. 
[7] Andreev, V.; Pryanichnikov, V.; Poduraev, Y. \& Kuvshinov, S. (2014) Education on the Basis of Virtual Learning Robotics Laboratory and Group-controlled Robots, in 24th DAAAM Int. Symp. on Intelligent Manufacturing and Automation, Procedia Engineering, vol. 69, pp. 35 - 40

[8] Ronkova, V. \& Haralanova, V. (2013). Communication Process with Students - a Condition for Improving the Quality of Teaching Process in Engineering Graphics, Scientific works of University of Ruse, Vol 52, No 9, Ruse, pp. 88-91, ISBN 1311-3321.

[9] Ronkova, V.; Dobreva, A.; Kamenov, K.; Dobrev, V. \& Dimitrov, Y. (2016). Increasing the Efficiency of the Study Process through Improving the Communication Activities between Students and Lecturers, Management and Sustainable Development, Vol 18, No 4, pp. 77 - 82, ISSN 1311-4506

[10] Dobreva, A. \& Haralanova, V. (2013). Measuring and Evaluation in Machine Science and Design Education, based upon Diagnostic Research, Procedia - Social and Behavioral Sciences, WCLTA, Brussels, 3rd World Conference on Learning, Teaching and Educational Leadership, Vol 93, pp. 1190-1194, ISSN 1877-0428.

[11] Kucak, D; Juricic, V. \& Dambic, G. (2018). Machine Learning in Education - a Survey of Current Research Trends, Proceedings of the 29th DAAAM International Symposium, pp.0406-0410, B. Katalinic (Ed.), Published by DAAAM International, ISBN 978-3-902734-20-4, ISSN 1726-9679, Vienna, Austria DOI: 10.2507/29th.daaam.proceedings.059

[12] Cus, F. \& Balic, J. (2013). New Requirements Facing the Training of Engineers for Economic Globalization, Chapter 29 in DAAAM International Scientific Book 2013, pp. 545-560, B. Katalinic \& Z. Tekic (Eds.), Published by DAAAM International, ISBN 978-3-901509-94-0, ISSN 1726-9687, Vienna, Austria DOI: 10.2507/daaam.scibook.2013.29

[13] Rudskoy, A.; Ipatov, O. \& Sergeev, S. (2017). Paradigms of Polytechnic Education in the Evolving Technogenic World, Chapter 12 in DAAAM International Scientific Book 2017, pp.145-154, B. Katalinic (Ed.), Published by DAAAM International, ISBN 978-3-902734-12-9, ISSN 1726-9687, Vienna, Austria, DOI: 10.2507/daaam.scibook.2017.12

[14] Stoyanov, S.; Dobrev, V. \& Dobreva, A. (2019). Investigation of the Opportunities for Experimental Research of Gear Train Vibrations, Proceedings of Power Transmissions, June 2019 in Varna, No 2, pp. 248 - 252, ISSN 978619-7383-12-6.

[15] Dobreva, A. \& Dobrev, V. (2007). Research of Technical Parameters of Transmissions for Vehicles and Agricultural Machines, UPB: Scientific Bulletin, Series D: Mechanical Engineering, Vol 69, pp. 103 - 109, ISSN 1454 - 2358.

[16] Pardanjac, M.; Eleven, E. \& Kaurovic, D. (2014). Increase of User Motivation in Teaching Realized Through Distance Learning, Chapter 10 in DAAAM International Scientific Book 2014, pp.131-144, B. Katalinic (Ed.), Published by DAAAM International, ISBN 978-3-901509-98-8, ISSN 1726-9687, Vienna, Austria DOI: 10.2507/daaam.scibook.2014.10

[17] Dimitrova, Y. \& Dimitrov, Y. (2018). The Non-Traditional Practice of Professional Student Club to Connect the Business with the Engineering Students of University of Ruse, Proceedings of the 29th DAAAM International Symposium, pp.1032-1037, B. Katalinic (Ed.), Published by DAAAM International, ISBN 978-3-902734-20-4, ISSN 1726-9679, Vienna, Austria, DOI: 10.2507/29th.daaam.proceedings.147

[18] Dimitrov, Y. \& Dimitrova, Y. (2018). Professional Club „SMART in CAD” - a Solution for Improving the Integration between Industry and Engineering Students, Management and Sustainable Development, Vol 20, No 1, ISSN 1311-4506. 